be multiplied to give $2854^{\circ} \mathrm{K}$. on the 1948 Scale (the current definition of colorimetric illuminant $A$ ) is equal to $1 \cdot 018$.

\section{Scottish Postgraduate Scholarship Awards in Agriculture}

THE Department of Agriculture for Scotland has awarded the following postgraduate scholarships in agricultural subjects, tenable for periods up to three years, commencing October 1 at the university or institute shown: Agricultural Economics, A. V. Vickery (Agricultural Economics Research Institute, Oxford) ; Husbandry, J. Eadie and A. O. Ballantyne (continuation of current award) (University of Edinburgh), D. S. Hay and R. R. Shepherd (University of Cambridge), R. Laird and T. D. MacLean (University of Reading), and A. F. Gristwood (continuation of current award) (Ohio State University) ; Statistics, St. C. S. Taylor (continuation of current award) (University of Edinburgh).

\section{University of London}

THE following announcements have recently been made from the University of London : the title of reader in mechanical engineering has been conferred on H. Hampson in respect of the post held by him at Queen Mary College; the degree of D.Sc. has been conferred on Miss Olive N. Purvis (Imperial College of Science and Technology) and C. A. Rogers (University College).

\section{University of Leeds}

THE University of Leeds has conferred the title of emeritus professor upon Prof. J. W. McLeod on the occasion of his retirement from the Brotherton chair of bacteriology. The following have been appointed lecturers in the University : Dr. R. W. Owen (zoology), F. R. Mobbs (mechanical engineering), and G. Hay, G. W. Reed and Miss Margaret T. Morrison (medical physics).

\section{Fourteenth International Congress of Zoology, Copenhagen}

THE Fourteenth International Congress of Zoology will be held in Copenhagen during August 5-12, 1953, under the presidency of Prof. R. Spärck, with Dr. Anton Fr. Bruun as secretary-general. It is proposed to hold three general meetings for all members of the Congress; but otherwise the proceedings will be divided into various sections, each dealing with specialized topics. Two excursions to West and East Jutland have been planned after the Congress, and possibly a third one to study marine fauna of the deeper part of the Skagerrak; no excursions will take place before August 5. Membership fee for the Congress is 100 Danish kroner (approximately $\mathfrak{£ 5} 5 s$. or 15 dollars).

\section{Conference on Race Problems}

THE British Social Biology Council is holding a one-day conference on Saturday, December 6, on race problems. The subject will be approached from three angles: the biological, the psychological and the anthropological. The main speakers will be Dr. A. F. Mourant, Dr. Kenneth L. Little, W. R. Bion and M. Freedman. Chairmen will include Dr. Julian Huxley and Dr. B. W. Gussman. The conference will be held in the Chemistry Lecture Theatre at University College, London, and tickets can be obtained from the Secretary,
British Social Biology Council, Tavistock House South, Tavistock Square, London, W.C.1, price $7 s$. $6 d$. (or $5 s$. for students whose applications are endorsed by some person of suitable status).

\section{Announcements}

H.R.H. The DUke of Edinburah will open the new wing of the Department of Engineering in the University of Cambridge on November 13.

SIr HarRy GaRner, chief scientist to the Ministry of Supply since 1949, is to retire early next year. He will be succeeded by Dr. O. H. Wansbrough-Jones, principal director of scientific research (defence) in the Ministry since January 1951 and formerly scientific adviser to the Army Council (see Nature, $157,688 ; 1946)$.

AT the opening session on October 4 of the academic year at the University of Liège, the degree of doctor of medicine honoris causa was conferred on Prof. Réné Fabre, doyen of the Faculty of Pharmacy, University of Paris, and on Prof. D. Keilin, director of the Molteno Institute, University of Cambridge.

The third meeting of the European Association of Exploration Geophysicists will be held in the Stadthalle, Corvinusplatz 2, Hannover, during December $4-5$, the business meeting being held the previous evening. Twenty papers from various European countries will be presented as follows: nine on seismic, seven on gravity, one on magnetic, two on telluric and electrical, and one on radioactivity methods of prospecting. Further particulars can be obtained from the secretary/treasurer, Dr. B. Baars, 30 Carel van Bylandtlaan, The Hague, or from Dr. D. T. Germain-Jones, Kirklington Hall, Nr. Newark, Notts.

UNDER the provisions of the Fulbright Programme, travel grants are available to citizens of the United Kingdom and British Colonies to go to the United States for academic or educational purposes, provided that they have the financial support in dollars for the visit and are affiliated to an American institution of higher learning. The grants cover the cost of direct travel from the candidate's home to America and return, and are available during June 1, 1953-May 31, 1954. Applications must be submitted by March 16, 1953 (those travelling between June 1 and July 31) or June 15 (those travelling after August 1). Further information can be obtained from the United States Educational Commission in the United Kingdom, 55 Upper Brook Street, London, W.1.

IN a notice of the Journal of Scientific Instruments published in Nature of August 23, p. 298, it was remarked that: "When the Journal was started in 1923 it was the only periodical devoted to ... scientific instruments". Mr. L. B. Tuckerman, of the National Bureau of Standards, Washington, D.C., points out that the first issue of the Journal of the Optical Society of America and Review of Scientific Instruments appeared in January 1922, and that the Zeitschrift für Instrumentkunde was a well-established journal by 1923, having been started in 1881 .

THE new photoelectric absorptiometer referred to in Nature of October 25, p. 694, is manufactured and sold by the Hilger Division of Hilger and Watts, Ltd., 98 St. Pancras Way, Camden Road, London, N.W.1. 